\title{
4
}

\section{From Multipotent Cells to Fully Differentiated Connective Tissue Cells for Regenerative Medicine: Emerging Applications of Mesenchymal Stem Cells}

\author{
Ali Mobasheri1, Stephen M. Richardson², Judith A. Hoyland², \\ Constanze Buhrmann ${ }^{3}$ and Mehdi Shakibaei ${ }^{3}$ \\ ${ }^{1}$ Musculoskeletal Research Group, Division of Veterinary Medicine, \\ School of Veterinary Medicine and Science, Faculty of Medicine and Health Science, \\ The University of Nottingham, Sutton Bonington Campus, Leicestershire, \\ ${ }^{2}$ Developmental Biomedicine Research Group, School of Biomedicine, \\ Faculty of Medical and Human Sciences, The University of Manchester, \\ Stopford Building, Oxford Road, Manchester, \\ ${ }^{3}$ Musculoskeletal Research Group, Institute of Anatomy, \\ Ludwig-Maximilian-University Munich, Munich \\ 1,2United Kingdom \\ ${ }^{3}$ Germany
}

\section{Introduction}

Mesenchymal stem cells (MSCs) are a heterogeneous subset of stromal cells that can be isolated from many adult tissues (Uccelli et al., 2008). Adult MSCs can be isolated from bone marrow, marrow aspirates, skeletal muscle, adipose tissue (Guilak et al., 2010), synovium and many other connective tissues (Barry, 2003). Due to their culture-dish adherence, they can be expanded in culture while maintaining their multipotency (Caplan, 2007). Their multipotency is an important property that allows them to differentiate into cells of the mesodermal lineage, giving rise to a range of specialized connective tissue cells including adipocytes, osteoblasts, chondrocytes and tenocytes as well as cells of other embryonic lineages (Figure 1) (Uccelli et al., 2008). MSCs have been isolated from humans and a variety of animal species including rodents, rabbits, dogs and horses. MSCs show considerable promise for use in repairing and rebuilding damaged or diseased mesenchymal tissues (Caplan, 2007). After in vivo administration, MSCs can induce peripheral tolerance and migrate to injured tissues where they have the capacity to exert immunosuppressive properties (Uccelli et al., 2007) and inhibit the release of pro-inflammatory cytokines and promote the survival of existing cells and the repair of damaged tissue (Uccelli et al., 2008). They are being clinically explored as a new therapeutic for treating a variety of immunemediated diseases (Parekkadan and Milwid, 2010). Thus, they have potential applications in tissue engineering and regenerative medicine and may represent an attractive option for bone, cartilage, tendon and ligament regeneration. 


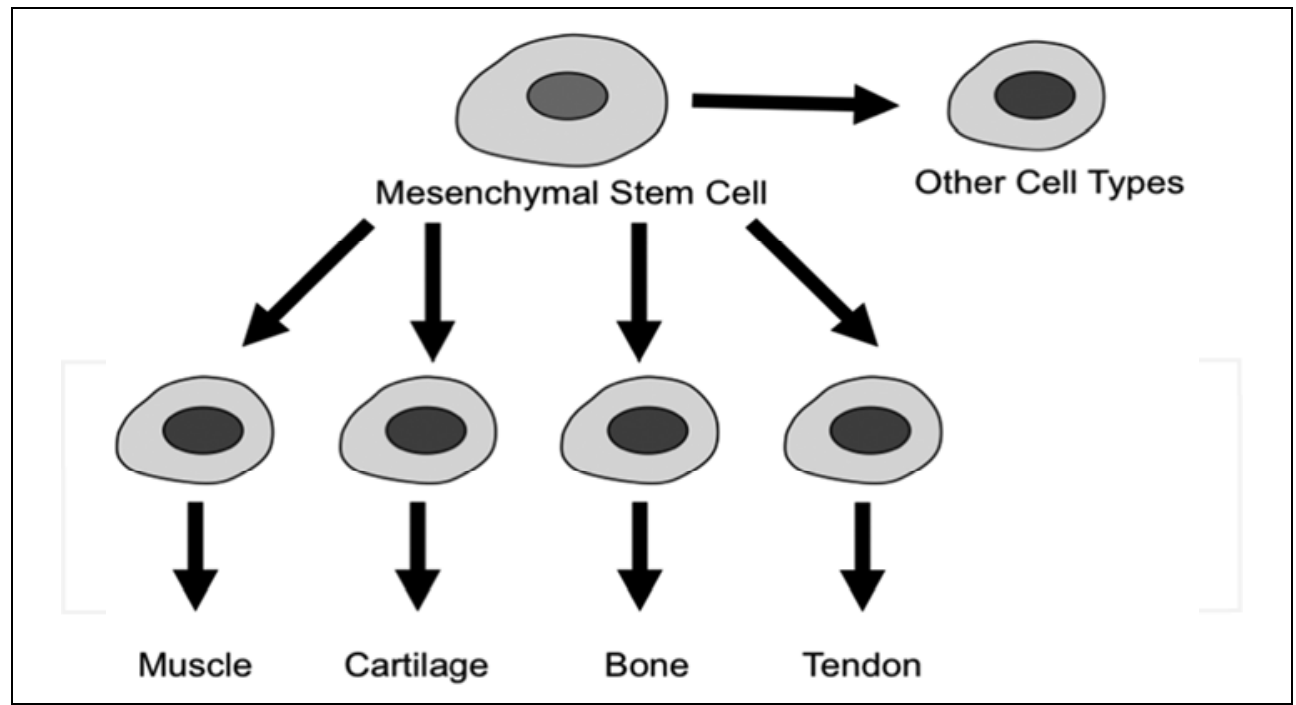

Fig. 1. Multipotency of mesenchymal stem cells (MSCs). MSCs can give rise to myocytes, chondrocytes, osteoblasts, tenocytes and a variety of other connective tissue cells

This chapter focuses on the potential of MSCs as an alternative to cells derived from patient tissues in autologous transplantation and tissue engineering. The prospects of using MSCs in regenerative medicine strategies are discussed and the advantages and disadvantages of these cells in articular cartilage tissue engineering are summarized. There is currently little consensus on how MSCs are best isolated, identified and characterized. This is partly due to the paucity of standardized specific cell surface markers. Although MSCs cells have been isolated and expanded in culture, their use for therapeutic strategies requires protocols and technologies that have not yet been clinically trialled and perfected (Caplan, 2005). Also, there are no established guidelines from governmental and intergovernmental agencies for their use in clinical applications. Even if these guidelines existed, more research is needed to help understand their basic biology since the therapeutic effects afforded by MSC transplantation are likely to be short-lived and related to dynamic, paracrine interactions between MSCs and host cells (Parekkadan and Milwid, 2010). MSCs possess a fibroblastic morphology but the published literature suggests that there is no well-defined phenotype for these cells. More work is needed to characterise the phenotype of these cells. This chapter will also focus on the conceptual and practical difficulties associated with differentiating and preconditioning MSCs for subsequent survival in a physiologically harsh extracellular matrix, an environment that will be highly hypoxic, acidic, and nutrient deprived. Interestingly, published data suggests that MSCs better differentiate into chondrocytes in low oxygen environments.

\section{Increasing life expectancy and the growing burden of musculoskeletal and joint diseases}

For the past 160 years human life expectancy has consistently increased by a quarter of a year every year (Oeppen and Vaupel, 2002). It is predicted that life expectancy will continue 
to increase by 2.5 years each decade, meaning that the western world's average life expectancy should reach and exceed 100 within the next 50 years (Oeppen and Vaupel, 2002). The increase in life expectancy has been mainly due to the significant advances in medicine and healthcare. However, the increased longevity of humans has greatly expanded the elderly population in the western world and has resulted in the increased prevalence of a range of arthritic, rheumatic and musculoskeletal disorders, which are placing an evergreater socioeconomic burden on health systems around the world as the population ages. According to the World Health Organization $(\mathrm{WHO})^{1}$, orthopaedic, rheumatic and musculoskeletal conditions comprise over 150 diseases and syndromes, which are usually progressive and associated with pain and disability. They can broadly be categorized as joint diseases, physical disability, spinal disorders, and conditions resulting from trauma. These conditions are leading causes of morbidity, giving rise to enormous healthcare expenditures and loss of productivity. Knowledge of the key determinants of disability in musculoskeletal conditions is critical for reducing their burden on the world's growing population (Oeppen and Vaupel, 2002; Weigl et al., 2008).

The United Nations, the WHO and 37 other countries have proclaimed the years 2000-2010 as the Bone and Joint Decade ${ }^{2}$ (McGowan, 2003; Woolf and Pfleger, 2003). This global initiative is intended to improve the lives of people with musculoskeletal disorders, such as arthritis, and to advance understanding and treatment of musculoskeletal disorders through prevention, education and research. The 10-year global initiative launched by the UN urges governments around the world to start taking action to draw attention to the growing pervasiveness and impact of musculoskeletal diseases and to reduce the social and financial burdens to society. Support for this global initiative will raise awareness of musculoskeletal health, stimulate research and improve people's quality of life.

Musculoskeletal diseases are one of the major causes of disability around the world and have been a significant reason for the development of the Bone and Joint Decade (Brooks, 2002; McGowan, 2003; Woolf and Pfleger, 2003). Rheumatoid arthritis (RA), osteoarthritis $(\mathrm{OA})$, gout and back pain are important causes of disability-adjusted-life years in both the developed and developing world (Brooks, 2006). The Arthritis Foundation ${ }^{3}$ in the United States plays a key role in co-ordinating efforts during the Bone and Joint Decade as a supporter. Its aims are to:

- Raise awareness and educate the world on the increasing societal impact of musculoskeletal injuries and disorders

- Empower patients to participate in decisions about their care and treatment

- Increase global funding for prevention activities and treatment research

- Continually seek and promote cost-effective prevention and treatment of musculoskeletal injuries and disorders

The major consequence of all forms of arthritis is joint dysfunction, disability, chronic pain, and significant morbidity. Aside from analgesics, there are currently no effective pharmacotherapies capable of restoring the structure and function of damaged synovial tissues in any form of arthritis. Consequently, there is an acute need for developing new tissue engineering and regenerative medicine strategies for arthritis.

\footnotetext{
${ }^{1}$ http://www.who.int/en/

${ }^{2}$ http://www.arthritis.org/bone-joint-decade.php

${ }^{3}$ http://www.arthritis.org/
} 


\section{The inflammatory component of musculoskeletal and joint diseases}

Many rheumatic diseases and arthritic conditions are essentially inflammatory disorders. The term "arthritis" characterizes a group of conditions involving damage to synovial joints. Arthritis literally means an inflammation (itis) of the joints (arthr). It involves pain, redness, heat, swelling and other harmful effects of inflammation within the joint. The most common form OA (also known as osteoarthrosis or degenerative joint disease) can result from trauma to the joint, infection of the joint, or simply as a consequence of ageing. Other forms of arthritis include psoriatic arthritis, and autoimmune diseases in which the body's immune system attacks itself such as RA. Inflammation plays slightly different roles in OA and RA. Inflammation is primarily the result of OA but in RA it is the root cause. The major consequence of arthritis is pain and disability. Pain is a constant and daily feature in wellestablished forms of the disease. Arthritis pain occurs due to inflammation that occurs around the joint, damage to the joint from disease, daily wear and tear of joint, muscular strains caused by movement against stiff, painful joints and fatigue. Disability in patients with arthritis is a consequence of degeneration in the joint and surrounding tissues and is further enhanced by inflammation-induced pain.

\section{Rheumatoid Arthritis (RA), Osteoarthritis (OA) and Lower Back Pain (LBP)}

The number of rheumatoid arthritis (RA) and osteoarthritis (OA) patients steadily rises as the elderly population grows in Western Europe, North America, and the rest of the developing world. RA, OA, and lower back pain (LBP) are important causes of disability adjusted-life years in both the developed and developing world (Brooks, 2006). Back and knee pain are common in the community and are likely to increase with the aging population (Brooks, 2006). Until recently OA was viewed as a "degenerative" or "wear-and tear" disease and held little interest for most clinicians. It is now accepted that the age related degeneration of articular cartilage as part of the clinical syndrome of OA is one of the most common causes of pain and disability in middle-aged and older people (Brooks, 2006). RA, OA and LBP pain are among the major causes of disability and morbidity within the adult population. OA is the most common form of joint disease, with the majority of the population over 65 years of age demonstrating radiographic evidence of $\mathrm{OA}$ in at least one joint. Likewise, around two- thirds of the adult population suffer from LBP at some point in their lifetime. LBP is also a major cause of disability and suffering globally (Grabias and Mankin, 1979; Jackson, 2004). LBP OA and RA are important causes of disability and are increasingly among the ageing population. LBP is also common among younger athletes and those older individuals who enjoy sports such as golf (Baker and Patel, 2005; McHardy and Pollard, 2005; Reed and Wadsworth, 2010).

The current inadequacy of treatments for these conditions, combined with their increasing prevalence exacerbates the burden on healthcare systems. Therefore, researchers and clinicians are striving for novel, innovative treatment options and the emergence of the fields of tissue engineering and regenerative medicine offer hope that long-term tissue repair may be possible. However, one of the current limiting factors for treatment of joint diseases is a source of cells. While a range of cell sources have been proposed, adult mesenchymal stem cells (MSCs) offer the greatest potential for clinical application.

Many studies have explored the prevalence of arthritis (OA and RA), related musculoskeletal conditions, LBP and intervertebral disc degeneration among elderly 
population. Chronic LBP is a major complaint of elderly patients and restricts most of their activities (with a higher prevalence in women). Interestingly LBP increases with age in men to reach the same frequency as women in those aged 90 years or older. Many studies have shown that a major cause of LBP is intervertebral disc degeneration, which is, primarily, an ageing related phenomenon. Degeneration of the intervertebral disc impacts not only on the disc, but also on the surrounding tissues such as the muscles and ligaments and affects the spine's ability to cope with the physiologically normal loads it experiences during a daily routine. As well as accelerating degeneration these changes also cause pain and reduce the mobility of the spine. The drug treatments currently available for LBP are inadequate and restricted to symptomatic pain control in mild cases and complicated and invasive surgical intervention (i.e. discectomy or spinal fusion) in severe cases. The increasing prevalence of LBP among the ageing population will become a major socioeconomic issue as it exacerbates the burden on healthcare systems throughout the developed world. Therefore new treatments are needed which restore full disc function and normalise disc cell biology.

\section{Regenerative medicine for RA and OA}

Bone and cartilage defects are common features of joint diseases, such as RA and OA (Noel et al., 2002). They have significant social and economic impact on the aging population. Despite progress in orthopaedic surgery, bone and cartilage repair is a major challenge as large defects will not spontaneously heal (Noel et al., 2002). Regenerative medicine is an emerging field that seeks to repair or replace injured tissues and organs through natural or bioengineered means. Recent research on stromal MSCs has provided a new and exciting opportunity for bone and cartilage tissue engineering. We have learned a great deal about the isolation, cultivation, and characterization of MSCs in recent years. A huge amount of research effort is now focused on their differentiation and models that exploit their regenerative potential. MSCs have generated a great deal of public, scientific, and media interest because of their potential use in regenerative medicine and tissue engineering (Tolar et al., 2010).

\section{Structure and function of articular cartilage}

Cartilage is a flexible and mechanically compliant connective tissue found at the end of long bones in articulating joints and in the intervertebral disc. It is sub-classified into three different types: elastic cartilage, hyaline cartilage and fibrocartilage, which differ in the relative amounts of its three principal components, namely collagen fibres, ground substance (proteoglycans) and elastic fibres. Articular or hyaline cartilage is a load-bearing tissue with unique biological characteristics (Figure 2). The biochemical properties of cartilage depend on the structural design of the tissue, the molecular composition of the extracellular matrix (ECM) that makes up the bulk of the tissue volume and the interactions between its resident cells and the ECM (Buckwalter and Mankin, 1998). Chondrocytes are the only cells found within the cartilage ECM. They are architects of cartilage (Muir, 1995), building the macromolecular framework of its ECM from three distinct classes of macromolecules: collagens (predominantly type II collagens), proteoglycans (mainly aggrecan), and a variety of non-collagenous proteins. Collagens type II, IX, and XI form a fibrillar meshwork that gives cartilage tensile stiffness and strength (Buckwalter and Mankin, 1998; Eyre, 2004; Kuettner et al., 1991), whereas collagen type VI forms part of the 
matrix immediately surrounding the chondrocytes, enabling them to attach to the macromolecular framework of the ECM and act as a transducer of biomechanical and biochemical signals in the articular cartilage (Guilak et al., 2006; Roughley and Lee, 1994). Large aggregating proteoglycans (aggrecan) are embedded in the ECM and give cartilage its stiffness to compression, its resilience and contribute to its long-term durability (Dudhia, 2005; Kiani et al., 2002; Luo et al., 2000; Roughley and Lee, 1994). Figure 3 illustrates the major molecular components of the cartilage ECM.

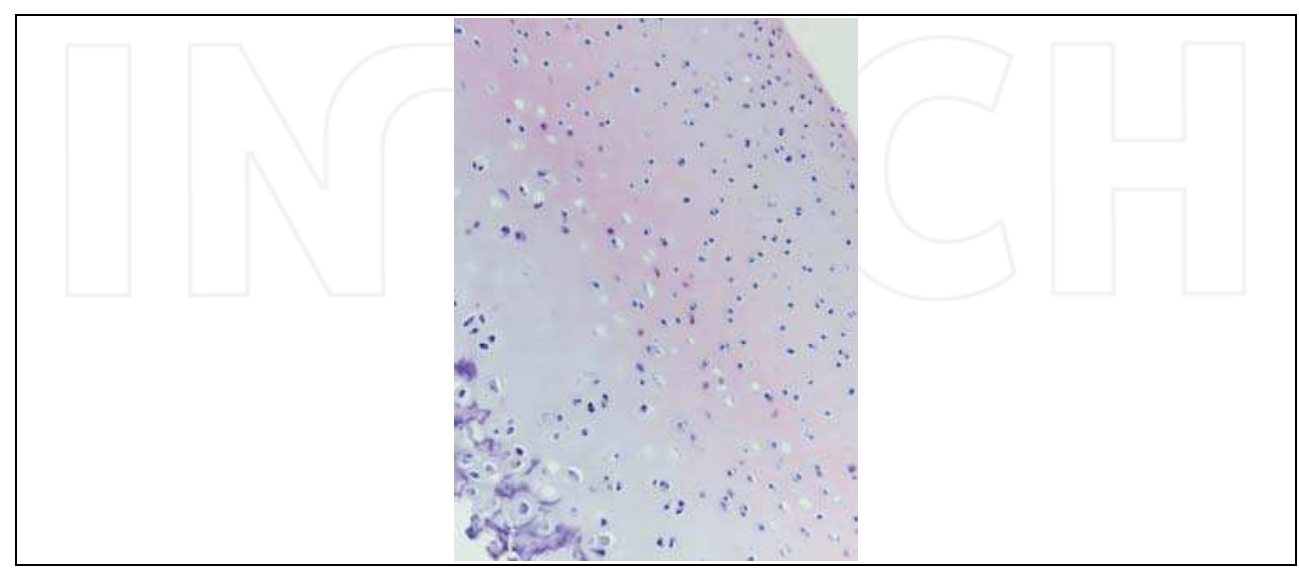

Fig. 2. A section of porcine articular cartilage showing the superficial, middle, deep and calcified zones

ECM proteins in cartilage are of great significance for the regulation of the cell behaviour, proliferation, differentiation and morphogenesis (Enomoto-Iwamoto et al., 1997; Gonzalez et al., 1993; Hewitt et al., 1982; Kosher and Church, 1975; Kosher et al., 1973; Ramachandrula et al., 1992; Ruoslahti and Reed, 1994; Sommarin et al., 1989; von der Mark et al., 1977). Small proteoglycans, including decorin, biglycan, and fibromodulin are further embedded in the ECM. Decorin and fibromodulin both interact with the type II collagen fibrils in the matrix and play a role in fibrillogenesis and interfibril interactions. Biglycan is mainly found in the immediate surrounding of the chondrocytes, where it may interact with collagen type VI (Buckwalter and Mankin, 1998; Roughley and Lee, 1994). Modulation of the ECM proteins is regulated by an interaction of a diversity of growth factors with chondrocytes (Hunziker et al., 1994; Isgaard, 1992; Jenniskens et al., 2006; Sah et al., 1994; Trippel et al., 1989). In fact, it has been reported recently, that IGF-I and TGF- $\beta$ stimulate the chondrocyte surface expression of integrins, and that this event is accompanied by increasing adhesion of chondrocytes to matrix proteins (Loeser, 1997). Other non-collagenous proteins in articular cartilage such as cartilage oligomeric matrix protein (COMP) are less well studied and may have a value as a biomarker of turnover and degeneration of cartilage (Di Cesare et al., 1996), while tenascin and fibronectin influence interactions between the chondrocytes and the ECM (Buckwalter and Mankin, 1998; Burton-Wurster et al., 1997). The ECM surrounds chondrocytes and protects them from biomechanical stress arousing during normal joint motion, determines the types and concentrations of molecules that reach the cells and helps to maintain the chondrocyte phenotype. 


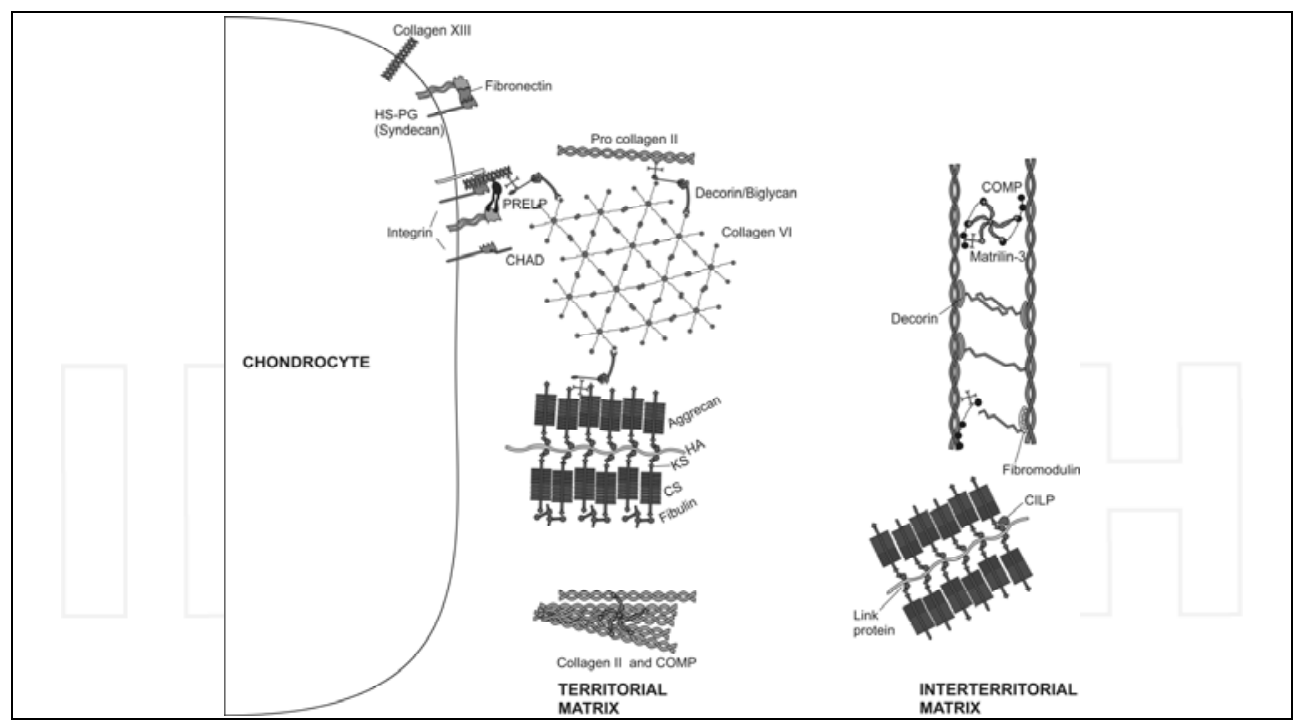

Fig. 3. Molecular composition of the extracellular matrix (ECM) of articular cartilage

Throughout life, cartilage undergoes continuous internal remodelling as chondrocytes replace matrix macromolecules lost through degradation. Evidence indicates that ECM turnover depends on the ability of chondrocytes to detect alterations in the macromolecular composition and organization of the matrix, including the presence of degraded macromolecules, and to respond by synthesizing appropriate types and amounts of new ECM components. It is known that mechanical loading of cartilage creates mechanical, electrical, and physicochemical signals that help to direct the synthesizing and degrading activity of chondrocytes (Mobasheri et al., 2002). In addition, the ECM acts as a signal transducer for chondrocytes (Millward-Sadler and Salter, 2004). A prolonged and severe decrease in the use of the joint leads to alterations in the composition of the ECM and eventually to a loss of tissue structure and its specific biomechanical properties, whereas normal physical strain stimulates the synthesizing activity of chondrocytes and possibly the internal tissue remodelling (Buckwalter and Lane, 1997; Maffulli and King, 1992).

Although articular cartilage can tolerate a tremendous amount of intensive and repetitive physical stress, it manifests a striking inability to heal even the most minor injury (Buckwalter, 2003; Buckwalter and Lane, 1997; Martin et al., 2004; Newman, 1998). This makes joints particularly sensitive to degenerative processes (Solursh, 1991). Furthermore, aging leads to alterations in the ECM composition and alters the activity of the chondrocytes, including their ability to respond to a variety of stimuli such as growth factors (Eckstein et al., 2001; Hudelmaier et al., 2001; Ralphs and Benjamin, 1994). All these alterations increase the probability of cartilage degeneration (Buckwalter, 2003; Poole, 1999; Sarzi-Puttini et al., 2005; Setton et al., 1999) and emphasize the importance of interaction of chondrocytes with their surrounding ECM since this interaction regulates their growth, differentiation, and survival in normal and pathophysiological conditions such as OA (Shakibaei et al., 1999). 


\section{Identification and application of Adult Stem Cells}

There are two types of stem cells: embryonic stem cells and non-embryonic "somatic" or "adult" stem cells. Embryonic stem cells are found in the blastocyst whereas adult stem cells are found in adult tissues. Adult stem cells maintain the normal turnover of organs with a high intrinsic regenerative capacity. These include blood, skin and intestinal epithelium. Adult stem cells can be found in children, adolescents as well as adults and are generally unipotent or multipotent. Pluripotent adult stem cells are very rare and are generally found in small numbers. However, they can be found in a number of tissues including umbilical cord blood. The best studied adult stem cells are multipotent and are generally referred to by their tissue origin (i.e. haematopoietic stem cells that differentiate into erythrocytes, white blood cells, platelets, etc. and bone marrow stromal cells also known as MSCs which have the capacity to differentiate into connective tissue cells (Pittenger et al., 1999) (see Figure 4).

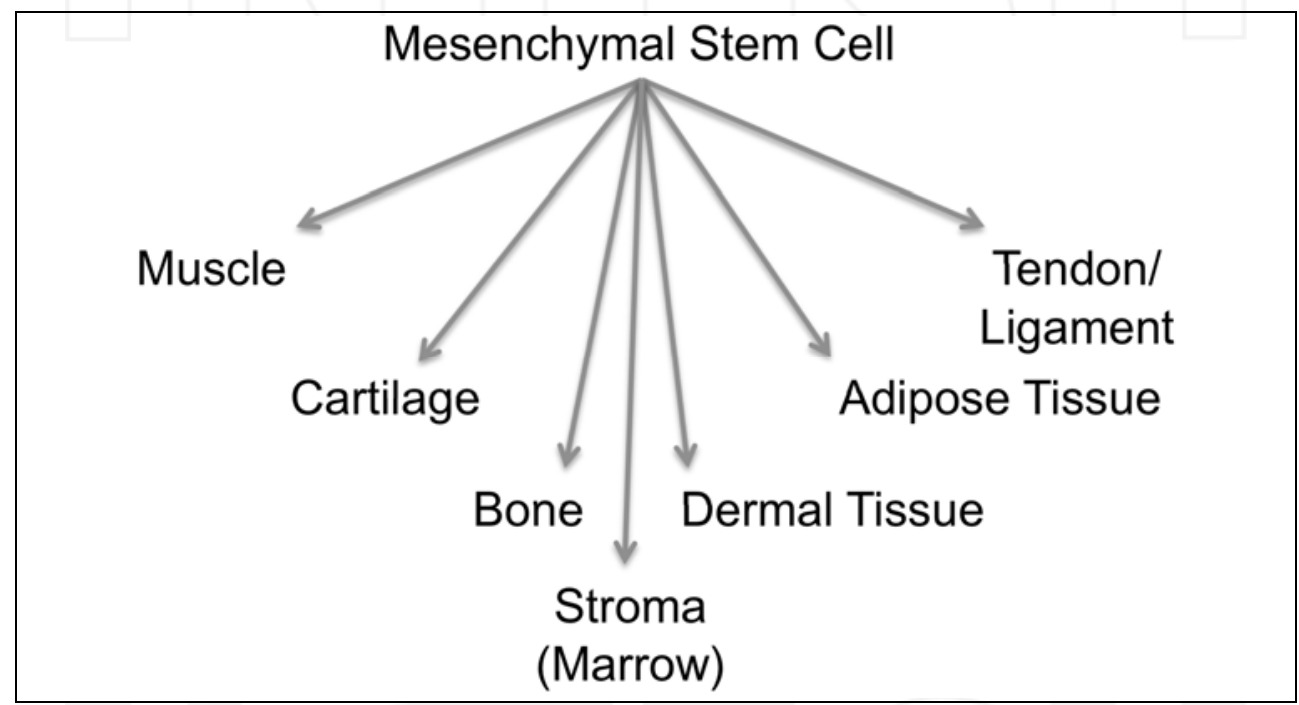

Fig. 4. Differentiation potential of human mesenchymal stem cells

These connective tissues include bone (Arinzeh, 2005; Hong et al., 2006; Noel et al., 2002), fat (Barry and Murphy, 2004; Helder et al., 2007), cartilage (Barry and Murphy, 2004; Caplan, 2007; Noel et al., 2002), intervertebral disc (Richardson et al., 2007; Trubiani et al., 2005; Trubiani et al., 2006), ligament (Sonoyama et al., 2006; Trubiani et al., 2005; Trubiani et al., 2006) and muscle (Barry and Murphy, 2004). Evidence suggests that these cells are also capable of differentiation along myogenic and neurogenic lineages, although these pathways are not normally utilised to demonstrate multipotentiality of isolated MSCs. Adult mesenchymal stem cells were originally isolated from bone marrow in 1999 by Pittinger and co-workers, who demonstrated their multilineage differentiation potential (Pittenger et al., 1999). Subsequent studies have identified the presence of stem cells in a number of adult tissues, including adipose, muscle, dermis, periosteum, synovial membrane, synovial fluid and articular cartilage. Thus far MSC-like progenitor cells have 
been isolated from bone marrow (Grigoriadis et al., 1988), periosteum, trabecular bone, adipose tissue, synovium, skeletal muscle and deciduous teeth (Barry and Murphy, 2004; Sonoyama et al., 2006). In fact they were known as marrow stromal cells long before they were known as MSCs (Grigoriadis et al., 1988). The International Society for Cellular Therapies has recently proposed a definiton for MSCs (Dominici et al., 2006). While there are no definitive markers of MSCs a range of cell surface markers are routinely used as markers of MSCs. These include immunopositivity for STRO-1, CD73, CD105, CD106 CD145 and CD166, combined with negative immunoreactivity for CD11b, CD31, CD34, CD45 and CD117. These markers can also be used to identify a more homogeneous population of cells than previous methods utilising either density-gradient centrifugation, or even simple plastic adherence. The general heterogeneity of bone marrow cell populations can lead to variable results; however MSCs are generally regarded to be capable of differentiation along the chondrogenic, osteogenic and adipogenic pathways. Work from our laboratories suggests that MSCs are capable of differentiation to nucleus pulposus (NP) cells of the IVD, chondrocytes and osteoblasts (Csaki et al., 2009; Csaki et al., 2007; Mobasheri et al., 2009; Richardson et al., 2007). However, since definite markers of NP cells have only recently been described (Minogue et al., 2010), a range of chondrocyte markers, with which they share a large phenotypic similarity, are routinely used (see Figure 5 and Table 1 for details of some of the currently investigated MSC markers).

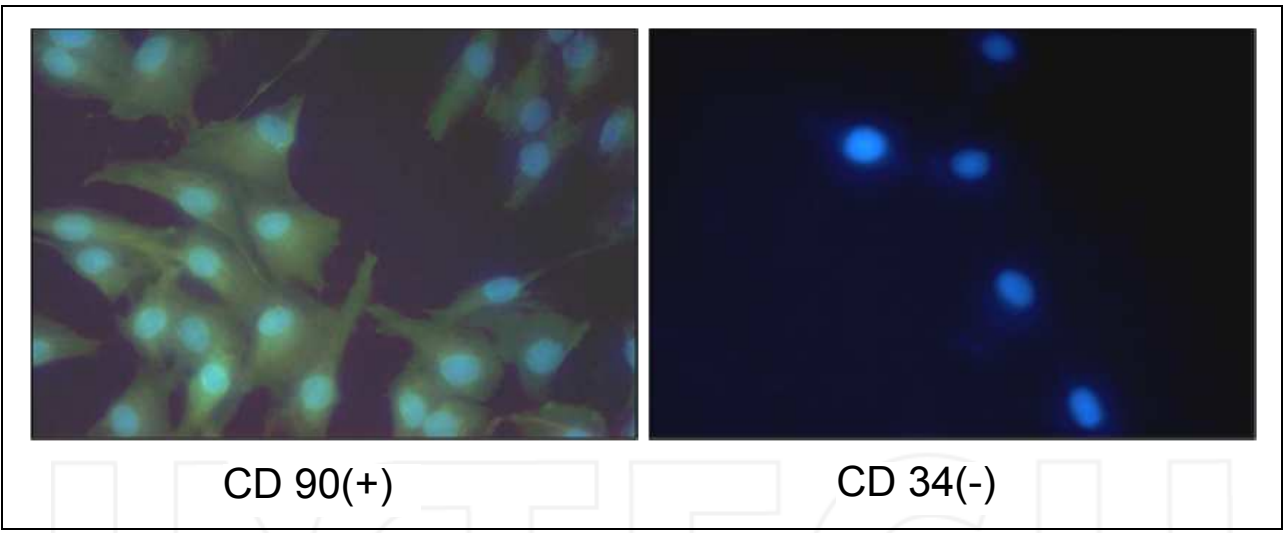

Fig. 5. Positive expression of CD 90 and lack of expression of CD 34 in canine mesenchymal stem cells

\section{Proliferation of research on Adult Stem Cells}

Since they were first identified by Pittinger and co-workers (Pittenger et al., 1999) research on adult stem cells has proliferated at a staggering pace. Work using adult stem cells does not involve many of the ethical challenges associated with using embryonic stem cells. Another reason for the rapid expansion in this area is the availability of a range of adult tissues from humans and animals. MSCs also posses neuroprotective (Uccelli et al., 2011) and cardioregenerative (Flynn and O'Brien, 2011) properties as well as the potential for musculoskeletal regeneration (O'Sullivan et al., 2011). 
Regenerative Medicine and Tissue Engineering - Cells and Biomaterials

\begin{tabular}{|c|c|c|c|}
\hline \multirow[t]{2}{*}{ Species } & \multirow[t]{2}{*}{ Source } & \multicolumn{2}{|c|}{ Cell surface markers } \\
\hline & & Positive & Negative \\
\hline Human & Adipose tissue & $\begin{array}{l}\text { CD13, CD29, CD44, CD73 and } \\
\text { CD90 }\end{array}$ & \\
\hline Canine & Bone marrow & CD90 and MHC-I & CD34, CD45 and MHC-II \\
\hline Human & $\begin{array}{l}\text { Bone marrow } \\
\text { Umbilical cord } \\
\text { blood } \\
\text { Adipose tissue }\end{array}$ & $\begin{array}{l}\text { CD29, CD44, CD73, CD90, } \\
\text { CD105, CD106 and HLA-I }\end{array}$ & $\begin{array}{l}\text { CD14, CD34, CD45, CD133, } \\
\text { CD144 and HLA-II }\end{array}$ \\
\hline Equine & Bone marrow & $\begin{array}{l}\text { CD90, fibronectin, perlecan and } \\
\text { collagen type IV }\end{array}$ & --- \\
\hline Equine & $\begin{array}{l}\text { Umbilical cord } \\
\text { matrix }\end{array}$ & $\begin{array}{l}\text { CD54, CD90, CD105, CD146, } \\
\text { Oct4, SSEA-4, c-Kit, SSEA-3 and } \\
\text { TRA-1-60 }\end{array}$ & CD34, CD45 and CD133 \\
\hline Canine & Bone marrow & CD90 and CD105 & CD34 and CD45 \\
\hline Equine & $\begin{array}{l}\text { Umbilical cord } \\
\text { blood }\end{array}$ & $\begin{array}{l}\text { Oct4, TRA-1-60, TRA-1-81 and } \\
\text { SSEA-1 }\end{array}$ & - \\
\hline Equine & Adipose tissue & Oct4, TRA-1-60 and TRA-1-81 & SSEA-1 and SSEA-4 \\
\hline Ovine & Bone marrow & CD44, vimentin and CD105 & CD34 and CD45 \\
\hline Human & Adipose tissue & $\begin{array}{l}\text { CD44, CD90, CD105, CD146, } \\
\text { CD166 and STRO-1 }\end{array}$ & CD14, CD31 and CD45 \\
\hline Human & Bone marrow & CD44, CD90, CD105 and CD166 & CD45 and CD117 \\
\hline Human & Bone marrow & $\begin{array}{l}\text { CD29, CD44, CD73, CD90, CD105 } \\
\text { and CD146 }\end{array}$ & CD14, CD34 and CD45 \\
\hline Human & $\begin{array}{l}\text { Infrapatellar fat } \\
\text { pad }\end{array}$ & $\begin{array}{l}\text { CD13, CD29, CD44, CD90, CD105 } \\
\text { and 3G5 }\end{array}$ & $\begin{array}{l}\text { CD34 CD56, LNGFR and } \\
\text { STRO-1 }\end{array}$ \\
\hline Human & $\begin{array}{l}\text { Infrapatellar fat } \\
\text { pad }\end{array}$ & $\begin{array}{l}\text { CD13, CD29, CD44, CD90 and } \\
\text { CD105 }\end{array}$ & $\begin{array}{l}\text { CD35, CD56, LNGFR and } \\
\text { STRO-1 }\end{array}$ \\
\hline Human & $\begin{array}{l}\text { Infrapatellar fat } \\
\text { pad }\end{array}$ & $\begin{array}{l}\text { CD13, CD29, CD44, CD90 and } \\
\text { CD105 }\end{array}$ & $\begin{array}{l}\text { CD34, CD56, LNGFR and } \\
\text { STRO-1 }\end{array}$ \\
\hline Ovine & Bone marrow & CD29, CD44 and CD166 & CD31 and CD45 \\
\hline Human & Bone marrow & CD44c, CD54, CD90 and STRO-1 & CD14 and CD45 \\
\hline Human & $\begin{array}{l}\text { Placental } \\
\text { chorionic villi }\end{array}$ & $\begin{array}{l}\text { CD49a/VLA-1, CD146, CD106, } \\
\text { 3G5, a-SMA and STRO-1 }\end{array}$ & X63 and vWF \\
\hline Canine & Adipose tissue & CD29, CD44 and CD90 & $\begin{array}{l}\text { CD13, CD31, CD34, CD45, } \\
\text { CD73, CD105 and CD117 }\end{array}$ \\
\hline Canine & $\begin{array}{l}\text { Umbilical cord } \\
\text { blood }\end{array}$ & $\begin{array}{l}\text { CD29, CD33, CD44, CD105, } \\
\text { CD184 and Oct4 }\end{array}$ & $\begin{array}{l}\text { CD4, CD8a, CD10, CD14, } \\
\text { CD20, CD24, CD31, CD34, } \\
\text { CD38, CD41a, CD41/61, } \\
\text { CD62p, CD73, CD90, CD133 } \\
\text { and HLA-DR }\end{array}$ \\
\hline Equine & Bone marrow & Sox-2, Oct4 and Nanog & CD34 \\
\hline Equine & Adipose tissue & CD90 and CD44 & CD13 \\
\hline Canine & Adipose tissue & CD44, CD90, CD140a and CD117 & CD34 and CD45 \\
\hline Canine & Adipose tissue & CD90 and CD105 & CD34 and CD45 \\
\hline
\end{tabular}

Table 1. Cell surface markers of MSCs from various species and tissue sources.

Data from Penny et al., (in press) 


\section{Musculoskeletal tissue regeneration}

Connective tissues, such as bone, cartilage, tendon, ligament and the IVD all suffer from both traumatic and age-related degenerative injuries. While bone repairs relatively well, the avascular and hypocellular nature of cartilage and in particular the IVD means these tissues suffer from a very limited self-repair capacity. During OA and IVD degeneration (one of the main causes of LBP) there is an imbalance between synthesis and degradation of the extracellular matrix which leads to an overall loss of tissue. This tissue destruction over time leads to pain and reduced mobility. While the increased repair capacity of bone prevents this, a number of metabolic and degenerative disorders, such as osteoporosis, osteonecrosis and Paget's disease, can cause bone loss or abnormal bone turnover. Traumatic injury and loss of bone following surgery for other diseases such as cancer can also lead to bone lesions which are too large for the body's self-regeneration capacity to cope with. Current clinical interventions for large bone defects, such as bone grafting, suffer from problems with donor site morbidity and limited material for large scale autologous grafts and infection or immune rejection with allogeneic grafts. The main histological, ECM and phenotypic markers of osteoblasts, chondrocytes and adipocytes differentiated from mesenchymal stem cells are shown in Table 2.

\begin{tabular}{|c|c|c|c|}
\hline & Osteoblasts & Chondrocytes & Adipocytes \\
\hline \multirow{4}{*}{$\begin{array}{l}\text { Histological } \\
\text { Stains }\end{array}$} & Alizarin Red & Toluidine Blue & Oil Red O \\
\hline & \multirow[t]{3}{*}{ von Kossa } & Alcian Blue & \\
\hline & & Safranin $\mathrm{O}$ & \\
\hline & & $\begin{array}{l}\text { Masson trichrome } \\
\text { stain C }\end{array}$ & \\
\hline \multirow[t]{2}{*}{ ECM Markers } & Type I collagen & Type II collagen & Type I collagen \\
\hline & Beta 1 integrin & Aggrecan & Beta 1 integrin \\
\hline \multirow{9}{*}{$\begin{array}{l}\text { Other } \\
\text { Markers }\end{array}$} & Alkaline phosphatase (ALP) & Sox9 & \\
\hline & Osteonectin (OSTN) & & \multirow{2}{*}{$\begin{array}{l}\text { Peroxisome proliferator- } \\
\text { activated receptor- } \\
\text { gamma (PPAR-gamma) }\end{array}$} \\
\hline & Osteocalcin (OCN) & & \\
\hline & $\begin{array}{l}\text { Runt-related transcription } \\
\text { factor-2 (Runx2) / Core }\end{array}$ & & $\begin{array}{c}\text { Fatty Acid Binding } \\
\text { Protein } 4 \text { (FABP4) }\end{array}$ \\
\hline & binding factor alpha 1 & & \\
\hline & Osteopontin (OPN) & & Lipoprotein Lipase (LPL) \\
\hline & \begin{tabular}{|c|} 
Bone Sialoprotein (BSP) \\
\end{tabular} & & \multirow[t]{3}{*}{ Leptin } \\
\hline & Vitamin D receptor (VDR) (14) & & \\
\hline & Homeobox gene MSX2 (14) & & \\
\hline
\end{tabular}

Table 2. The main histological, ECM and phenotypic markers of osteoblasts, chondrocytes and adipocytes differentiated from mesenchymal stem cells. Data from Penny et al., (in press)

These limitations in current clinical treatments for bone defects and disorders have led to the development of tissue engineering strategies using both synthetic and natural scaffold implants. Materials such as tricalcium phosphates (Guo et al., 2004a; Guo et al., 2004b; Jiang et al., 2007; Shao et al., 2006; Solchaga et al., 1999), calcium carbonates (Kreklau et al., 1999), hydroxyapatite (Chajra et al., 2008; Reddi, 2000; Yoshikawa and Myoui, 2005) and Bioglass (Helen and Gough, 2008; Wilda and Gough, 2006) have all been utilised alongside growth 
factors to promote new growth, or act as supports for implanted cells to regenerate new tissue. These materials all aim to mimic the specialised microenvironment or bone and cartilage and are growing in their clinical application.

Articular cartilage and the IVD share similarities in cellular phenotype and extra-cellular matrix composition. Consequently similar approaches have been adopted for tissue engineering cartilage and IVD (Kalson et al., 2008; Richardson et al., 2007). As with bone repair, there are major limitations to current clinical treatments for OA and IVD degeneration. Scaffold-free autologous chondrocyte implantation (ACI) is currently used clinically to treat small cartilage lesions, such as those caused by traumatic injury. For this treatment a biopsy is taken from a non-load bearing region of cartilage, the chondrocytes enzymatically extracted, expanded in monolayer culture, then reimplanted into the lesion and covered with a periosteal flap (Brittberg et al., 1994). The therapy has been used to treat over 12,000 patients worldwide and offers cartilage repair and reduced pain equivalent to existing surgical cartilage repair therapies (Peterson et al., 2002). However, while this treatment appears to work well for small cartilage lesions it has limited practical application for larger osteoarthritic lesions.

Cell implantation into degenerate IVDs has been demonstrated in animal models to both inhibit degeneration and regenerate tissue (Ganey et al., 2003). A small-scale study in human patients comparing standard discectomy for disc prolapse with discectomy plus autologous disc cell implantation demonstrated improvements in pain reduction, preservation of disc height and prevention of adjacent disc segment degeneration in patients who underwent the cell implantation therapy (Meisel et al., 2006; Meisel et al., 2007). Clinical follow-up data is limited and there is no biochemical or biomechanical data, but this study demonstrates the potential for cell-based therapies for IVD tissue regeneration. However, studies suggest that isolation of cells from degenerate IVD could accelerate degeneration, while isolation of cells from non-degenerate levels may induce degenerative changes and needle puncture is a common method of inducting degeneration in animal models of disease (Kim et al., 2005; Korecki et al., 2008; Masuda et al., 2006; Zhang et al., 2009). Additionally, as IVD degeneration, like OA in cartilage, affects the phenotype of resident cells the identification of a suitable cell source for novel tissue engineering and regenerative medicine strategies is one of the key determinants of its success.

Cells used in tissue engineering must survive within the graft site and produce a suitable and functional matrix, which mimics, or even improves on the original tissue. Autologous chondrocyte implantation (ACI) has been shown to be effective in the treatment of osteoarthritic cartilage lesions, producing a type II collagen and proteoglycan-rich matrix which restores function to the joint (Gillogly et al., 1998). Similarly, implantation of chondrocytes within a 3-dimensional carrier system such as a collagen gel has also been shown to produce a cartilaginous matrix, which could be of clinical use (Gavenis et al., 2006; Sakai et al., 2006).

\section{Microenvironmental challenges for MSC-based tissue regeneration: The 3-D environment and oxygenation}

One of the major challenges facing MSC-based tissue engineering is mimicking and recreating the microenvironment of the tissue that is being regenerated. MSCs destined for tissue engineering must be able to survive in a physiologically harsh extracellular matrix, an environment that will be highly hypoxic, acidic, and nutrient deprived. In addition, this 
environment may be exposed to dynamic compressive forces or rich in pro-inflammatory mediators that could induce catabolic and apoptotic responses in MSCs. Culturing the cells in a high-density 3-D environment is a good starting point and clearly has a number of benefits. High-density culture (see Figure 6) is a 3-dimensional system that has been in the literature since the early 1970's. High-density suspension cultures of chondrocytes were initially used to study cartilage matrix protein synthesis by mammalian chondrocytes (Kuettner et al., 1982a; Kuettner et al., 1982b), specifically mucoprotein (Nevo and Dorfman, 1972) and proteoglycan (Handley and Lowther, 1976) biosynthesis. In an important study published in 1977 the method was refined by von der Mark and von der Mark who used tissue culture plastic dishes on an agar base to monitor chondrogenesis of stage- 24 chick limb mesodermal cells in vitro by analyzing the onset of type II collagen synthesis (von der Mark and von der Mark, 1977). This work demonstrated that high-density cultures may be used for the analysis of cell specific types of collagen and provide a useful model for detailing the specific events in the differentiation of mesenchymal cells in vitro. Several subsequent studies used chick limb bud mesenchymal cells and chick sternal chondrocytes cultured in high-density to study chondrogenesis and proteoglycan synthesis (Lohmander et al., 1979) and fibronectin expression (Hassell et al., 1979). We have used this culture system as a model for chondrogenic, osteogenic and tenogenic differentiation of MSCs and redifferentiation of dedifferentiated chondrocytes (Csaki et al., 2009; Csaki et al., 2007; Seifarth et al., 2009; Shakibaei et al., 2006) (see Figure 7). The high-density model exhibits a number of characteristics that make it particularly suitable for studied on chondrogenesis. In the first 24 hours of the high-density chondrocyte culture, cells form prechondrogenic areas composed of densely packed cells with intercellular interactions (gap junctions); these are surrounded by a perichondrium of flat fibroblast-like cells (Shakibaei et al., 1993) resembling the situation during the early stage of chondrogenesis in vivo. The extensive cellcell interactions during the first step of chondrogenesis are crucial for cell aggregation (Denker et al., 1999; Loty et al., 2000). The high-density culture system allows investigations during chondrogenesis starting from early blastema/mesenchymal stem cell condensations until cartilage maturation. This chondrogenic development is accompanied by enlargement of cartilage nodules, which is not due to cell proliferation but rather is due to appositional growth, which includes the transition of perichondral cells into chondrocytes. These conclusions are based on the almost complete absence of mitotic figures in cartilage and perichondrium and on the continuous increase in nodule size during cultivation (Denker et al., 1999).

In addition to 3-D environment, the presence of member(s) of the transforming growth factor (TGF- $\beta$ ) family and low oxygen tension have been reported to promote the in vitro differentiation of MSCs (Ronziere et al., 2010). Appropriate levels of oxygenation can be powerful determinants of MSC differentiation. For example, low oxygen tension is a more potent promoter of chondrogenic differentiation than dynamic compression (Meyer et al., 2010). Enhanced chondrogenic differentiation of human bone marrow-derived MSCs has been observed in a low oxygen environment in micropellet cultures (Khan et al., 2010; Markway et al., 2010). Clearly oxygen tension is an important determinant of MSC differentiation; hypoxia, cell aggregation and TGF- $\beta$ delivery are crucial for achieving complete chondrogenesis (Mobasheri et al., 2009; Richardson et al., 2007). Although MSCs may possess a superior potential to generate a functional repair tissue in low oxygen tensions, in the context of in vitro cartilage tissue engineering, cells maintained in normoxic conditions in the presence of TGF- $\beta$ generate the most mechanically functional tissue 
(Buckley et al., 2010). Physiologically low oxygen tension during monolayer expansion of MSCs has been shown to be advantageous in order to improve cartilage tissue engineering in a sheep model (Zscharnack et al., 2009). The information available in the literature leads to the conclusion that MSCs in culture function optimally in an atmosphere of reduced oxygen that more closely approximates documented in vivo oxygen tension (Lennon et al., 2001). These observations apply to cells derived from OA patients (Khan et al., 2007). Clearly fine adjustments to these conditions in future studies could produce an engineered tissue with the desirable mechanical and biological properties.

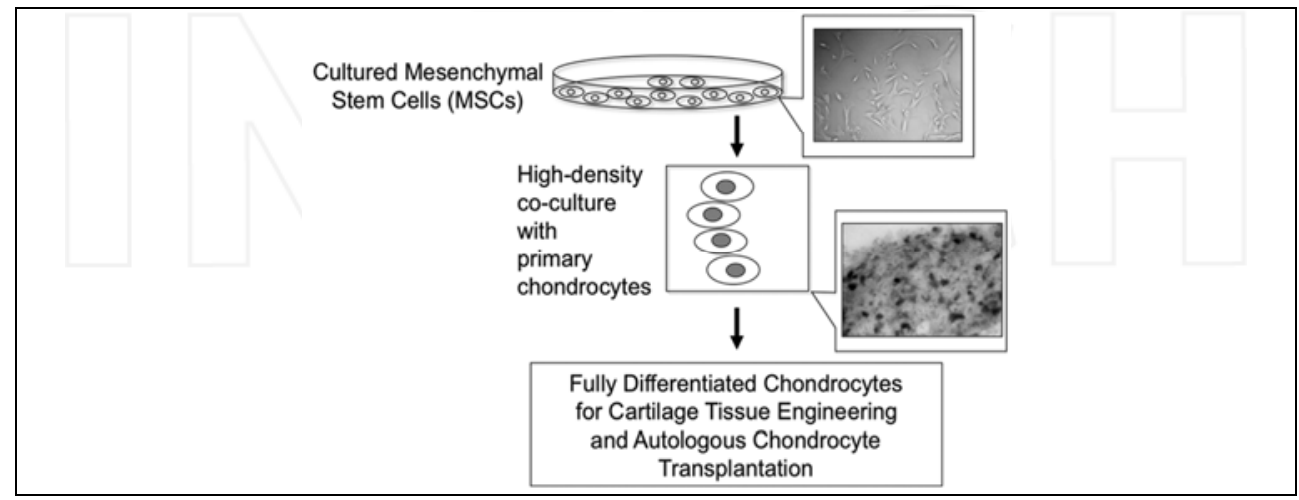

Fig. 6. 3-Dimensional high-density culture of mesenchymal stem cells (MSCs) and primary chondrocytes. The MSCs in this high-density model are stimulated to undergo chondrogenesis by the co-cultured primary chondrocytes

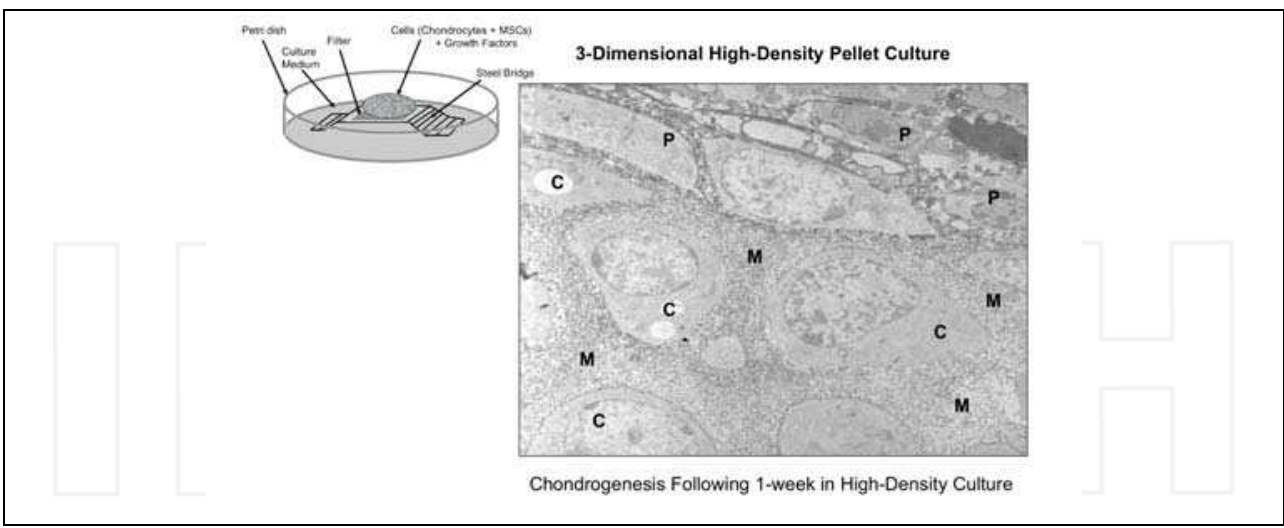

Fig. 7. 3-Dimensional high-density culture. In this model chondrocytes (C) are maintained in a pellet at the air-liquid interface, which will allow them to maintain their phenotype and produce an extracellular matrix $(\mathrm{M})$. Cells at the periphery form a perichondrium-like layer of cells $(\mathrm{P})$

One proposed method to ensure MSC survival and function following implantation into the degenerate tissue is to pre-condition, or pre-differentiate the cells. A recent study by Wuertz 
and co-workers (Wuertz et al., 2008) demonstrated that when cultured in an intervertebral disc-like environment containing low glucose, low $\mathrm{pH}$ and high osmolarity, MSCs demonstrated a lower proliferation rate and lower expression of matrix genes compared to standard conditions, highlighting the importance of the microenvironmental niche on MSC biology. In particular, low $\mathrm{pH}$ has been shown to inhibit expression of aggrecan by MSCs (Wuertz et al., 2009a), while the presence of catabolic cytokines IL-1 $\beta$ and TNF- $\alpha$, which are increased in both disc degeneration and OA, inhibited chondrogenesis of MSCs (Wehling et al., 2009).

\section{High density cultures of MSCs: "3Rs" models for engineering biomimetic models of articular cartilage}

A number of animal models of arthritis have been developed to study arthritic disease pathogenesis and evaluate the efficacy of candidate anti-inflammatory and anti-arthritic drugs for clinical development (Aigner et al., 2010; Ameye and Young, 2006; Brandt, 1991, 1994; Goldring, 1999; Koch and Betts, 2007; van den Berg, 2001). These animal models may involve injection of inflammatory agents into the joint, surgical creation of joint instability or surgical replication of joint trauma. Such models not only cause a considerable amount of pain and suffering but also none of them have a proven track record of predictability in human disease. Consequently, there is an acute need for developing novel and alternative in vitro models that mimic the biology of cartilage (Freed et al., 2006; Oreffo and Triffitt, 1999; Reddi, 1998, 2000; Sittinger et al., 2004). Many studies have used articular cartilage and synovial tissues to establish in vitro models of the joint. In our laboratories we have developed explant models of articular cartilage inflammation, co-cultures of primary synoviocytes and chondrocytes as well as 3-dimensional high-density cultures of chondrocytes and MSCs (Buhrmann et al., 2010; Csaki et al., 2009; Csaki et al., 2007; Mobasheri et al., 2009; Richardson et al., 2010). We have also determined the potential of phytochemicals as stimulators of chondrogenic differentiation. These culture models of MSCs, fully differentiated cells and co-cultures have potential of as "proof of principle" ethically acceptable " $3 \mathrm{Rs}^{\prime}$ " models for engineering biomimetic models of articular cartilage in vitro for the purpose of replacing and reducing the use of animals in arthritis research. This approach could help reduce the number of laboratory animals used in arthritis research and may provide a realistic alternative to experimental animals.

\section{Conclusions}

One of the major conceptual difficulties in designing or applying clinically based MSC therapies to cartilage and intervertebral disc degeneration is the complexity and heterogeneity of disease among patients. New information obtained from in vitro studies and animal models are useful. However, the information gained from some animal models cannot be interpolated directly for translational studies in human patients with cartilage or disc degeneration. For example, stem cell therapy may not be applied across the entire spectrum of cartilage and intervertebral disc degeneration; the therapy may well work in cases that involve very early morphological and degenerative changes but success may not be guaranteed in cases where the damage and degeneration is extensive. It is difficult to conceive how MSCs and tissue engineering may be clinically useful in extreme cases where the cartilage has completely worn away or the disc has collapsed completely. Therefore, the 
variability among the human patient population complicates the concept of stem cell based therapy and introduces a very large element of risk, which may inhibit or impede the translational potential of regenerative medicine using MSCs.

Several clinical trials have already begun to evaluate the use and efficacy of mesenchymal stem cells and biomaterials in arthritic diseases of joints and the spine. At the present time too many gaps remain, both clinically and scientifically, before such approaches can be used safely and rationally. Interest in tissue engineering of cartilage and intervertebral disc is increasing and cartilage tissue engineering has been investigated for over 20 years. However, none of the approaches available for cartilage for example have been able to achieve the consistency, effectiveness and reliability required for clinical applications. Tissue engineering of a mechanically resilient disc that meets the structural and functional criteria for effective functional integration into a defect site in the host is a difficult endeavour. One of the fundamental weaknesses of all the tissue engineered models available to date is that none of them possess the normal zonal organization of cells that is seen in vivo (i.e. annulus fibrosus and nucleus pulposus regions) and the local composition of extracellular matrix in each zone. This structural organisation is a pre-requisite for normal disc function and the success of any future clinical applications.

For the foreseeable future the molecular determinants of MSC differentiation into chondrogenic and osteogenic lineages continue to be elucidated using existing 2D models. However, new research using 3D models is more likely to shed light on fundamental processes such as paracrine-mediated differentiation, and mechanisms responsible for the recruitment of endogenous progenitor populations in response to chemical, biological, and physical cues. Furthermore, three-dimensional and high-density culture models have huge potential as "3Rs" models for replacing and reducing the use of animals in arthritis research. There are numerous animal models for OA and other types of arthritis. However, none of them have a proven track record of predictability for the equivalent disease in humans and the majority of them are plagued with problems. Three-dimensional culture conditions, hypoxia and the use of specially supplemented culture media will ultimately need to be assessed in pre-clinical animal models that closely mimic the human disease. However, 3D culture models utilizing tissue engineered articular cartilage and IVD should help us carry out better and more focused research as well as reducing the number and variety of experimental animals used before moving onto larger and more expensive preclinical animal models.

Bone marrow and adipose tissue derived MSCs possess the potential for chondrogenic, osteogenic and tenogenic differentiation in the presence of appropriate cellular stimuli. Stable induction can be achieved with a combination of endocrine and environmental factors (i.e. co-culture of MSCs and primary cells), or through culturing MSCs with spent media from primary chondrocyte, osteoblast or tendon cell cultures. Therefore, these results point to new ways in which MSCs might be manipulated in culture for future therapeutic strategies for cartilage, bone and tendon tissue engineering.

Regenerative medicine relies on the optimistic view that stem cells, allogeneic tissue transplantation, patient derived adult stem cells and biomaterials may be used for repairing and regenerating tissues and organs in the future. Although we should maintain this optimistic view, it would be prudent to consider the numerous hurdles and complicating factors that need to be overcome as research progresses in this exciting and rapidly expanding field. 


\section{Acknowledgments}

The authors thank their collaborators Professor Anthony J. Freemont (University of Manchester) and Professor Pablo Martin-Vasallo (University of La Laguna, Tenerife). This study was made possible by grants from The Wellcome Trust, the National Centre for the Replacement, Refinement and Reduction of Animals in Research (NC3Rs) (grant number: Mobasheri.A.28102007), the Biotechnology and Biological Sciences Research Council (BBSRC) (grants BBSRC/S/M/2006/ 13141 and BB/G018030/1) and the Engineering and Physical Sciences Research Council (EPSRC), UK. We would like to thank the members of our laboratories for their support and collaboration.

\section{References}

Aigner, T., Cook, J.L., Gerwin, N., Glasson, S.S., Laverty, S., Little, C.B., McIlwraith, W., Kraus, V.B., 2010. Histopathology atlas of animal model systems - overview of guiding principles. Osteoarthritis Cartilage 18 Suppl 3, S2-6.

Ameye, L.G., Young, M.F., 2006. Animal models of osteoarthritis: lessons learned while seeking the "Holy Grail". Curr Opin Rheumatol 18, 537-547.

Arinzeh, T.L., 2005. Mesenchymal stem cells for bone repair: preclinical studies and potential orthopedic applications. Foot Ankle Clin 10, 651-665, viii.

Baker, R.J., Patel, D., 2005. Lower back pain in the athlete: common conditions and treatment. Prim Care 32, 201-229.

Barry, F.P., 2003. Mesenchymal stem cell therapy in joint disease. Novartis Found Symp 249, 86-96; discussion 96-102, 170-104, 239-141.

Barry, F.P., Murphy, J.M., 2004. Mesenchymal stem cells: clinical applications and biological characterization. Int J Biochem Cell Biol 36, 568-584.

Brandt, K.D., 1991. Transection of the anterior cruciate ligament in the dog: a model of osteoarthritis. Semin Arthritis Rheum 21, 22-32.

Brandt, K.D., 1994. Insights into the natural history of osteoarthritis provided by the cruciate-deficient dog. An animal model of osteoarthritis. Ann N Y Acad Sci 732, 199-205.

Brittberg, M., Lindahl, A., Nilsson, A., Ohlsson, C., Isaksson, O., Peterson, L., 1994. Treatment of deep cartilage defects in the knee with autologous chondrocyte transplantation. N Engl J Med 331, 889-895.

Brooks, P.M., 2002. Impact of osteoarthritis on individuals and society: how much disability? Social consequences and health economic implications. Curr Opin Rheumatol 14, 573-577.

Brooks, P.M., 2006. The burden of musculoskeletal disease--a global perspective. Clin Rheumatol 25, 778-781.

Buckley, C.T., Vinardell, T., Kelly, D.J., 2010. Oxygen tension differentially regulates the functional properties of cartilaginous tissues engineered from infrapatellar fat pad derived MSCs and articular chondrocytes. Osteoarthritis Cartilage 18, 1345-1354.

Buckwalter, J.A., 2003. Sports, joint injury, and posttraumatic osteoarthritis. J Orthop Sports Phys Ther 33, 578-588.

Buckwalter, J.A., Lane, N.E., 1997. Athletics and osteoarthritis. Am J Sports Med 25, 873-881.

Buckwalter, J.A., Mankin, H.J., 1998. Articular cartilage: tissue design and chondrocytematrix interactions. Instr Course Lect 47, 477-486. 
Buhrmann, C., Mobasheri, A., Matis, U., Shakibaei, M., 2010. Curcumin mediated suppression of nuclear factor-kappaB promotes chondrogenic differentiation of mesenchymal stem cells in a high-density co-culture microenvironment. Arthritis Res Ther 12, R127.

Burton-Wurster, N., Lust, G., Macleod, J.N., 1997. Cartilage fibronectin isoforms: in search of functions for a special population of matrix glycoproteins. Matrix Biol 15, 441-454.

Caplan, A.I., 2005. Review: mesenchymal stem cells: cell-based reconstructive therapy in orthopedics. Tissue Eng 11, 1198-1211.

Caplan, A.I., 2007. Adult mesenchymal stem cells for tissue engineering versus regenerative medicine. J Cell Physiol 213, 341-347.

Chajra, H., Rousseau, C.F., Cortial, D., Ronziere, M.C., Herbage, D., Mallein-Gerin, F., Freyria, A.M., 2008. Collagen-based biomaterials and cartilage engineering. Application to osteochondral defects. Biomed Mater Eng 18, S33-45.

Csaki, C., Matis, U., Mobasheri, A., Shakibaei, M., 2009. Co-culture of canine mesenchymal stem cells with primary bone-derived osteoblasts promotes osteogenic differentiation. Histochem Cell Biol 131, 251-266.

Csaki, C., Matis, U., Mobasheri, A., Ye, H., Shakibaei, M., 2007. Chondrogenesis, osteogenesis and adipogenesis of canine mesenchymal stem cells: a biochemical, morphological and ultrastructural study. Histochem Cell Biol 128, 507-520.

Denker, A.E., Haas, A.R., Nicoll, S.B., Tuan, R.S., 1999. Chondrogenic differentiation of murine C3H10T1/2 multipotential mesenchymal cells: I. Stimulation by bone morphogenetic protein-2 in high-density micromass cultures. Differentiation 64, 67-76.

Di Cesare, P.E., Carlson, C.S., Stolerman, E.S., Hauser, N., Tulli, H., Paulsson, M., 1996. Increased degradation and altered tissue distribution of cartilage oligomeric matrix protein in human rheumatoid and osteoarthritic cartilage. J Orthop Res 14, 946-955.

Dominici, M., Le Blanc, K., Mueller, I., Slaper-Cortenbach, I., Marini, F., Krause, D., Deans, R., Keating, A., Prockop, D., Horwitz, E., 2006. Minimal criteria for defining multipotent mesenchymal stromal cells. The International Society for Cellular Therapy position statement. Cytotherapy 8, 315-317.

Dudhia, J., 2005. Aggrecan, aging and assembly in articular cartilage. Cell Mol Life Sci 62, 2241-2256.

Eckstein, F., Reiser, M., Englmeier, K.H., Putz, R., 2001. In vivo morphometry and functional analysis of human articular cartilage with quantitative magnetic resonance imaging--from image to data, from data to theory. Anat Embryol (Berl) 203, 147-173.

Enomoto-Iwamoto, M., Iwamoto, M., Nakashima, K., Mukudai, Y., Boettiger, D., Pacifici, M., Kurisu, K., Suzuki, F., 1997. Involvement of alpha5beta1 integrin in matrix interactions and proliferation of chondrocytes. J Bone Miner Res 12, 1124-1132.

Eyre, D.R., 2004. Collagens and cartilage matrix homeostasis. Clin Orthop Relat Res, S118-122.

Flynn, A., O'Brien, T., 2011. Stem cell therapy for cardiac disease. Expert Opin Biol Ther 11, 177-187.

Freed, L.E., Guilak, F., Guo, X.E., Gray, M.L., Tranquillo, R., Holmes, J.W., Radisic, M., Sefton, M.V., Kaplan, D., Vunjak-Novakovic, G., 2006. Advanced tools for tissue engineering: scaffolds, bioreactors, and signaling. Tissue Eng 12, 3285-3305.

Ganey, T., Libera, J., Moos, V., Alasevic, O., Fritsch, K.G., Meisel, H.J., Hutton, W.C., 2003. Disc chondrocyte transplantation in a canine model: a treatment for degenerated or damaged intervertebral disc. Spine (Phila Pa 1976) 28, 2609-2620. 
Gavenis, K., Schmidt-Rohlfing, B., Mueller-Rath, R., Andereya, S., Schneider, U., 2006. In vitro comparison of six different matrix systems for the cultivation of human chondrocytes. In Vitro Cell Dev Biol Anim 42, 159-167.

Gillogly, S.D., Voight, M., Blackburn, T., 1998. Treatment of articular cartilage defects of the knee with autologous chondrocyte implantation. J Orthop Sports Phys Ther 28, 241-251.

Goldring, M.B., 1999. The role of cytokines as inflammatory mediators in osteoarthritis: lessons from animal models. Connect Tissue Res 40, 1-11.

Gonzalez, F.A., Seth, A., Raden, D.L., Bowman, D.S., Fay, F.S., Davis, R.J., 1993. Seruminduced translocation of mitogen-activated protein kinase to the cell surface ruffling membrane and the nucleus. J Cell Biol 122, 1089-1101.

Grabias, S.L., Mankin, H.J., 1979. Pain in the lower back. Bull Rheum Dis 30, 1040-1045.

Grigoriadis, A.E., Heersche, J.N., Aubin, J.E., 1988. Differentiation of muscle, fat, cartilage, and bone from progenitor cells present in a bone-derived clonal cell population: effect of dexamethasone. J Cell Biol 106, 2139-2151.

Guilak, F., Alexopoulos, L.G., Upton, M.L., Youn, I., Choi, J.B., Cao, L., Setton, L.A., Haider, M.A., 2006. The pericellular matrix as a transducer of biomechanical and biochemical signals in articular cartilage. Ann N Y Acad Sci 1068, 498-512.

Guilak, F., Estes, B.T., Diekman, B.O., Moutos, F.T., Gimble, J.M., 2010. 2010 Nicolas Andry Award: Multipotent adult stem cells from adipose tissue for musculoskeletal tissue engineering. Clin Orthop Relat Res 468, 2530-2540.

Guo, X., Wang, C., Duan, C., Descamps, M., Zhao, Q., Dong, L., Lu, S., Anselme, K., Lu, J., Song, Y.Q., 2004a. Repair of osteochondral defects with autologous chondrocytes seeded onto bioceramic scaffold in sheep. Tissue Eng 10, 1830-1840.

Guo, X., Wang, C., Zhang, Y., Xia, R., Hu, M., Duan, C., Zhao, Q., Dong, L., Lu, J., Qing Song, Y., 2004b. Repair of large articular cartilage defects with implants of autologous mesenchymal stem cells seeded into beta-tricalcium phosphate in a sheep model. Tissue Eng 10, 1818-1829.

Handley, C.J., Lowther, D.A., 1976. Inhibition of proteoglycan biosynthesis by hyaluronic acid in chondrocytes in cell culture. Biochim Biophys Acta 444, 69-74.

Hassell, J.R., Pennypacker, J.P., Kleinman, H.K., Pratt, R.M., Yamada, K.M., 1979. Enhanced cellular fibronectin accumulation in chondrocytes treated with vitamin A. Cell 17, 821-826.

Helder, M.N., Knippenberg, M., Klein-Nulend, J., Wuisman, P.I., 2007. Stem cells from adipose tissue allow challenging new concepts for regenerative medicine. Tissue Eng 13, 1799-1808.

Helen, W., Gough, J.E., 2008. Cell viability, proliferation and extracellular matrix production of human annulus fibrosus cells cultured within PDLLA/Bioglass composite foam scaffolds in vitro. Acta Biomater 4, 230-243.

Hewitt, A.T., Varner, H.H., Silver, M.H., Martin, G.R., 1982. The role of chondronectin and cartilage proteoglycan in the attachment of chondrocytes to collagen. Prog Clin Biol Res 110 Pt B, 25-33.

Hong, L., Colpan, A., Peptan, I.A., 2006. Modulations of 17-beta estradiol on osteogenic and adipogenic differentiations of human mesenchymal stem cells. Tissue Eng 12, 2747 2753.

Hudelmaier, M., Glaser, C., Hohe, J., Englmeier, K.H., Reiser, M., Putz, R., Eckstein, F., 2001. Age-related changes in the morphology and deformational behavior of knee joint cartilage. Arthritis Rheum 44, 2556-2561. 
Hunziker, E.B., Wagner, J., Zapf, J., 1994. Differential effects of insulin-like growth factor I and growth hormone on developmental stages of rat growth plate chondrocytes in vivo. J Clin Invest 93, 1078-1086.

Isgaard, J., 1992. Expression and regulation of IGF-I in cartilage and skeletal muscle. Growth Regul 2, 16-22.

Jackson, K.C., 2nd, 2004. Pharmacotherapy in lower back pain. Drugs Today (Barc) 40, 765-772.

Jenniskens, Y.M., Koevoet, W., de Bart, A.C., Weinans, H., Jahr, H., Verhaar, J.A., DeGroot, J., van Osch, G.J., 2006. Biochemical and functional modulation of the cartilage collagen network by IGF1, TGFbeta2 and FGF2. Osteoarthritis Cartilage 14, 1136-1146.

Jiang, C.C., Chiang, H., Liao, C.J., Lin, Y.J., Kuo, T.F., Shieh, C.S., Huang, Y.Y., Tuan, R.S., 2007. Repair of porcine articular cartilage defect with a biphasic osteochondral composite. J Orthop Res 25, 1277-1290.

Kalson, N.S., Richardson, S., Hoyland, J.A., 2008. Strategies for regeneration of the intervertebral disc. Regen Med 3, 717-729.

Khan, W.S., Adesida, A.B., Hardingham, T.E., 2007. Hypoxic conditions increase hypoxiainducible transcription factor 2alpha and enhance chondrogenesis in stem cells from the infrapatellar fat pad of osteoarthritis patients. Arthritis Res Ther 9, R55.

Khan, W.S., Adesida, A.B., Tew, S.R., Lowe, E.T., Hardingham, T.E., 2010. Bone marrowderived mesenchymal stem cells express the pericyte marker 3G5 in culture and show enhanced chondrogenesis in hypoxic conditions. J Orthop Res 28, 834-840.

Kiani, C., Chen, L., Wu, Y.J., Yee, A.J., Yang, B.B., 2002. Structure and function of aggrecan. Cell Res 12, 19-32.

Kim, K.S., Yoon, S.T., Li, J., Park, J.S., Hutton, W.C., 2005. Disc degeneration in the rabbit: a biochemical and radiological comparison between four disc injury models. Spine (Phila Pa 1976) 30, 33-37.

Koch, T.G., Betts, D.H., 2007. Stem cell therapy for joint problems using the horse as a clinically relevant animal model. Expert Opin Biol Ther 7, 1621-1626.

Korecki, C.L., Costi, J.J., Iatridis, J.C., 2008. Needle puncture injury affects intervertebral disc mechanics and biology in an organ culture model. Spine (Phila Pa 1976) 33, 235-241.

Kosher, R.A., Church, R.L., 1975. Stimulation of in vitro somite chondrogenesis by procollagen and collagen. Nature 258, 327-330.

Kosher, R.A., Lash, J.W., Minor, R.R., 1973. Environmental enhancement of in vitro chondrogenesis. IV. Stimulation of somite chondrogenesis by exogenous chondromucoprotein. Dev Biol 35, 210-220.

Kreklau, B., Sittinger, M., Mensing, M.B., Voigt, C., Berger, G., Burmester, G.R., Rahmanzadeh, R., Gross, U., 1999. Tissue engineering of biphasic joint cartilage transplants. Biomaterials 20, 1743-1749.

Kuettner, K.E., Aydelotte, M.B., Thonar, E.J., 1991. Articular cartilage matrix and structure: a minireview. J Rheumatol Suppl 27, 46-48.

Kuettner, K.E., Memoli, V.A., Pauli, B.U., Wrobel, N.C., Thonar, E.J., Daniel, J.C., 1982a. Synthesis of cartilage matrix by mammalian chondrocytes in vitro. II. Maintenance of collagen and proteoglycan phenotype. J Cell Biol 93, 751-757.

Kuettner, K.E., Pauli, B.U., Gall, G., Memoli, V.A., Schenk, R.K., 1982b. Synthesis of cartilage matrix by mammalian chondrocytes in vitro. I. Isolation, culture characteristics, and morphology. J Cell Biol 93, 743-750. 
Lennon, D.P., Edmison, J.M., Caplan, A.I., 2001. Cultivation of rat marrow-derived mesenchymal stem cells in reduced oxygen tension: effects on in vitro and in vivo osteochondrogenesis. J Cell Physiol 187, 345-355.

Loeser, R.F., 1997. Growth factor regulation of chondrocyte integrins. Differential effects of insulin-like growth factor 1 and transforming growth factor beta on alpha 1 beta 1 integrin expression and chondrocyte adhesion to type VI collagen. Arthritis Rheum 40, 270-276.

Lohmander, L.S., Hascall, V.C., Caplan, A.I., 1979. Effects of 4-methyl umbelliferyl-beta-Dxylopyranoside on chondrogenesis and proteoglycan synthesis in chick limb bud mesenchymal cell cultures. J Biol Chem 254, 10551-10561.

Loty, S., Foll, C., Forest, N., Sautier, J.M., 2000. Association of enhanced expression of gap junctions with in vitro chondrogenic differentiation of rat nasal septal cartilagereleased cells following their dedifferentiation and redifferentiation. Arch Oral Biol $45,843-856$.

Luo, W., Guo, C., Zheng, J., Chen, T.L., Wang, P.Y., Vertel, B.M., Tanzer, M.L., 2000. Aggrecan from start to finish. J Bone Miner Metab 18, 51-56.

Maffulli, N., King, J.B., 1992. Effects of physical activity on some components of the skeletal system. Sports Med 13, 393-407.

Markway, B.D., Tan, G.K., Brooke, G., Hudson, J.E., Cooper-White, J.J., Doran, M.R., 2010. Enhanced chondrogenic differentiation of human bone marrow-derived mesenchymal stem cells in low oxygen environment micropellet cultures. Cell Transplant 19, 29-42.

Martin, J.A., Brown, T., Heiner, A., Buckwalter, J.A., 2004. Post-traumatic osteoarthritis: the role of accelerated chondrocyte senescence. Biorheology 41, 479-491.

Masuda, K., Imai, Y., Okuma, M., Muehleman, C., Nakagawa, K., Akeda, K., Thonar, E., Andersson, G., An, H.S., 2006. Osteogenic protein-1 injection into a degenerated disc induces the restoration of disc height and structural changes in the rabbit anular puncture model. Spine (Phila Pa 1976) 31, 742-754.

McGowan, J.A., 2003. Perspectives on the future of bone and joint diseases. J Rheumatol Suppl 67, 62-64.

McHardy, A., Pollard, H., 2005. Lower back pain in golfers: a review of the literature. J Chiropr Med 4, 135-143.

Meisel, H.J., Ganey, T., Hutton, W.C., Libera, J., Minkus, Y., Alasevic, O., 2006. Clinical experience in cell-based therapeutics: intervention and outcome. Eur Spine J 15 Suppl 3, S397-405.

Meisel, H.J., Siodla, V., Ganey, T., Minkus, Y., Hutton, W.C., Alasevic, O.J., 2007. Clinical experience in cell-based therapeutics: disc chondrocyte transplantation A treatment for degenerated or damaged intervertebral disc. Biomol Eng 24, 5-21.

Meyer, E.G., Buckley, C.T., Thorpe, S.D., Kelly, D.J., 2010. Low oxygen tension is a more potent promoter of chondrogenic differentiation than dynamic compression. J Biomech 43, 2516-2523.

Millward-Sadler, S.J., Salter, D.M., 2004. Integrin-dependent signal cascades in chondrocyte mechanotransduction. Ann Biomed Eng 32, 435-446.

Minogue, B.M., Richardson, S.M., Zeef, L.A., Freemont, A.J., Hoyland, J.A., 2010. Characterization of the human nucleus pulposus cell phenotype and evaluation of novel marker gene expression to define adult stem cell differentiation. Arthritis Rheum 62, 3695-3705. 
Mobasheri, A., Carter, S.D., Martin-Vasallo, P., Shakibaei, M., 2002. Integrins and stretch activated ion channels; putative components of functional cell surface mechanoreceptors in articular chondrocytes. Cell Biol Int 26, 1-18.

Mobasheri, A., Csaki, C., Clutterbuck, A.L., Rahmanzadeh, M., Shakibaei, M., 2009. Mesenchymal stem cells in connective tissue engineering and regenerative medicine: applications in cartilage repair and osteoarthritis therapy. Histol Histopathol 24, 347-366.

Muir, H., 1995. The chondrocyte, architect of cartilage. Biomechanics, structure, function and molecular biology of cartilage matrix macromolecules. Bioessays 17, 1039-1048.

Nevo, Z., Dorfman, A., 1972. Stimulation of chondromucoprotein synthesis in chondrocytes by extracellular chondromucoprotein. Proc Natl Acad Sci U S A 69, 2069-2072.

Newman, A.P., 1998. Articular cartilage repair. Am J Sports Med 26, 309-324.

Noel, D., Djouad, F., Jorgense, C., 2002. Regenerative medicine through mesenchymal stem cells for bone and cartilage repair. Curr Opin Investig Drugs 3, 1000-1004.

O'Sullivan, J., D'Arcy, S., Barry, F.P., Murphy, J.M., Coleman, C.M., 2011. Mesenchymal chondroprogenitor cell origin and therapeutic potential. Stem Cell Res Ther 2, 8 .

Oeppen, J., Vaupel, J.W., 2002. Demography. Broken limits to life expectancy. Science 296, 1029-1031.

Oreffo, R.O., Triffitt, J.T., 1999. Future potentials for using osteogenic stem cells and biomaterials in orthopedics. Bone 25, 5S-9S.

Parekkadan, B., Milwid, J.M., 2010. Mesenchymal stem cells as therapeutics. Annu Rev Biomed Eng 12, 87-117.

Penny, J., Harris, P., Shakesheff, K., Mobasheri, A., 2011. The biology of equine mesenchymal stem cells: phenotypic characterization, cell surface markers and multilineage differentiation. Front Biosci (in press)

Peterson, L., Brittberg, M., Kiviranta, I., Akerlund, E.L., Lindahl, A., 2002. Autologous chondrocyte transplantation. Biomechanics and long-term durability. Am J Sports Med 30, 2-12.

Pittenger, M.F., Mackay, A.M., Beck, S.C., Jaiswal, R.K., Douglas, R., Mosca, J.D., Moorman, M.A., Simonetti, D.W., Craig, S., Marshak, D.R., 1999. Multilineage potential of adult human mesenchymal stem cells. Science 284, 143-147.

Poole, A.R., 1999. An introduction to the pathophysiology of osteoarthritis. Front Biosci 4, D662-670.

Ralphs, J.R., Benjamin, M., 1994. The joint capsule: structure, composition, ageing and disease. J Anat 184 ( Pt 3), 503-509.

Ramachandrula, A., Tiku, K., Tiku, M.L., 1992. Tripeptide RGD-dependent adhesion of articular chondrocytes to synovial fibroblasts. J Cell Sci 101 ( Pt 4), 859-871.

Reddi, A.H., 1998. Role of morphogenetic proteins in skeletal tissue engineering and regeneration. Nat Biotechnol 16, 247-252.

Reddi, A.H., 2000. Morphogenesis and tissue engineering of bone and cartilage: inductive signals, stem cells, and biomimetic biomaterials. Tissue Eng 6, 351-359.

Reed, J.J., Wadsworth, L.T., 2010. Lower back pain in golf: a review. Curr Sports Med Rep 9, 57-59.

Richardson, S.M., Hoyland, J.A., Mobasheri, R., Csaki, C., Shakibaei, M., Mobasheri, A., 2010. Mesenchymal stem cells in regenerative medicine: opportunities and challenges for articular cartilage and intervertebral disc tissue engineering. J Cell Physiol 222, 23-32. 
Richardson, S.M., Mobasheri, A., Freemont, A.J., Hoyland, J.A., 2007. Intervertebral disc biology, degeneration and novel tissue engineering and regenerative medicine therapies. Histol Histopathol 22, 1033-1041.

Ronziere, M.C., Perrier, E., Mallein-Gerin, F., Freyria, A.M., 2010. Chondrogenic potential of bone marrow- and adipose tissue-derived adult human mesenchymal stem cells. Biomed Mater Eng 20, 145-158.

Roughley, P.J., Lee, E.R., 1994. Cartilage proteoglycans: structure and potential functions. Microsc Res Tech 28, 385-397.

Ruoslahti, E., Reed, J.C., 1994. Anchorage dependence, integrins, and apoptosis. Cell 77, 477478.

Sah, R.L., Chen, A.C., Grodzinsky, A.J., Trippel, S.B., 1994. Differential effects of bFGF and IGF-I on matrix metabolism in calf and adult bovine cartilage explants. Arch Biochem Biophys 308, 137-147.

Sakai, D., Mochida, J., Iwashina, T., Watanabe, T., Suyama, K., Ando, K., Hotta, T., 2006. Atelocollagen for culture of human nucleus pulposus cells forming nucleus pulposus-like tissue in vitro: influence on the proliferation and proteoglycan production of HNPSV-1 cells. Biomaterials 27, 346-353.

Sarzi-Puttini, P., Cimmino, M.A., Scarpa, R., Caporali, R., Parazzini, F., Zaninelli, A., Atzeni, F., Canesi, B., 2005. Osteoarthritis: an overview of the disease and its treatment strategies. Semin Arthritis Rheum 35, 1-10.

Seifarth, C., Csaki, C., Shakibaei, M., 2009. Anabolic actions of IGF-I and TGF-beta1 on Interleukin-1beta-treated human articular chondrocytes: evaluation in two and three dimensional cultures. Histol Histopathol 24, 1245-1262.

Setton, L.A., Elliott, D.M., Mow, V.C., 1999. Altered mechanics of cartilage with osteoarthritis: human osteoarthritis and an experimental model of joint degeneration. Osteoarthritis Cartilage 7, 2-14.

Shakibaei, M., John, T., De Souza, P., Rahmanzadeh, R., Merker, H.J., 1999. Signal transduction by beta1 integrin receptors in human chondrocytes in vitro: collaboration with the insulin-like growth factor-I receptor. Biochem J $342 \mathrm{Pt} \mathrm{3,} \mathrm{615-623.}$

Shakibaei, M., Schroter-Kermani, C., Merker, H.J., 1993. Matrix changes during long-term cultivation of cartilage (organoid or high-density cultures). Histol Histopathol 8, 463470.

Shakibaei, M., Seifarth, C., John, T., Rahmanzadeh, M., Mobasheri, A., 2006. Igf-I extends the chondrogenic potential of human articular chondrocytes in vitro: molecular association between Sox9 and Erk1/2. Biochem Pharmacol 72, 1382-1395.

Shao, X., Goh, J.C., Hutmacher, D.W., Lee, E.H., Zigang, G., 2006. Repair of large articular osteochondral defects using hybrid scaffolds and bone marrow-derived mesenchymal stem cells in a rabbit model. Tissue Eng 12, 1539-1551.

Sittinger, M., Hutmacher, D.W., Risbud, M.V., 2004. Current strategies for cell delivery in cartilage and bone regeneration. Curr Opin Biotechnol 15, 411-418.

Solchaga, L.A., Dennis, J.E., Goldberg, V.M., Caplan, A.I., 1999. Hyaluronic acid-based polymers as cell carriers for tissue-engineered repair of bone and cartilage. J Orthop Res 17, 205-213.

Solursh, M., 1991. Formation of cartilage tissue in vitro. J Cell Biochem 45, 258-260.

Sommarin, Y., Larsson, T., Heinegard, D., 1989. Chondrocyte-matrix interactions. Attachment to proteins isolated from cartilage. Exp Cell Res 184, 181-192. 
Sonoyama, W., Liu, Y., Fang, D., Yamaza, T., Seo, B.M., Zhang, C., Liu, H., Gronthos, S., Wang, C.Y., Shi, S., Wang, S., 2006. Mesenchymal stem cell-mediated functional tooth regeneration in swine. PLoS ONE 1, e79.

Tolar, J., Le Blanc, K., Keating, A., Blazar, B.R., 2010. Concise review: hitting the right spot with mesenchymal stromal cells. Stem Cells 28, 1446-1455.

Trippel, S.B., Corvol, M.T., Dumontier, M.F., Rappaport, R., Hung, H.H., Mankin, H.J., 1989. Effect of somatomedin-C/insulin-like growth factor I and growth hormone on cultured growth plate and articular chondrocytes. Pediatr Res 25, 76-82.

Trubiani, O., Di Primio, R., Traini, T., Pizzicannella, J., Scarano, A., Piattelli, A., Caputi, S., 2005. Morphological and cytofluorimetric analysis of adult mesenchymal stem cells expanded ex vivo from periodontal ligament. Int J Immunopathol Pharmacol 18, 213221.

Trubiani, O., Orsini, G., Caputi, S., Piatelli, A., 2006. Adult mesenchymal stem cells in dental research: a new approach for tissue engineering. Int J Immunopathol Pharmacol 19, 451-460.

Uccelli, A., Benvenuto, F., Laroni, A., Giunti, D., 2011. Neuroprotective features of mesenchymal stem cells. Best Pract Res Clin Haematol 24, 59-64.

Uccelli, A., Moretta, L., Pistoia, V., 2008. Mesenchymal stem cells in health and disease. Nat Rev Immunol 8, 726-736.

Uccelli, A., Pistoia, V., Moretta, L., 2007. Mesenchymal stem cells: a new strategy for immunosuppression? Trends Immunol 28, 219-226.

van den Berg, W.B., 2001. Lessons from animal models of osteoarthritis. Curr Opin Rheumatol 13, 452-456.

von der Mark, K., Gauss, V., von der Mark, H., Muller, P., 1977. Relationship between cell shape and type of collagen synthesised as chondrocytes lose their cartilage phenotype in culture. Nature 267, 531-532.

von der Mark, K., von der Mark, H., 1977. Immunological and biochemical studies of collagen type transition during in vitro chrondrogenesis of chick limb mesodermal cells. J Cell Biol 73, 736-747.

Weigl, M., Cieza, A., Cantista, P., Reinhardt, J.D., Stucki, G., 2008. Determinants of disability in chronic musculoskeletal health conditions: a literature review. Eur J Phys Rehabil Med 44, 67-79.

Wilda, H., Gough, J.E., 2006. In vitro studies of annulus fibrosus disc cell attachment, differentiation and matrix production on PDLLA/45S5 Bioglass composite films. Biomaterials 27, 5220-5229.

Woolf, A.D., Pfleger, B., 2003. Burden of major musculoskeletal conditions. Bull World Health Organ 81, 646-656.

Yoshikawa, H., Myoui, A., 2005. Bone tissue engineering with porous hydroxyapatite ceramics. J Artif Organs 8, 131-136.

Zhang, H., La Marca, F., Hollister, S.J., Goldstein, S.A., Lin, C.Y., 2009. Developing consistently reproducible intervertebral disc degeneration at rat caudal spine by using needle puncture. J Neurosurg Spine 10, 522-530.

Zscharnack, M., Poesel, C., Galle, J., Bader, A., 2009. Low oxygen expansion improves subsequent chondrogenesis of ovine bone-marrow-derived mesenchymal stem cells in collagen type I hydrogel. Cells Tissues Organs 190, 81-93. 


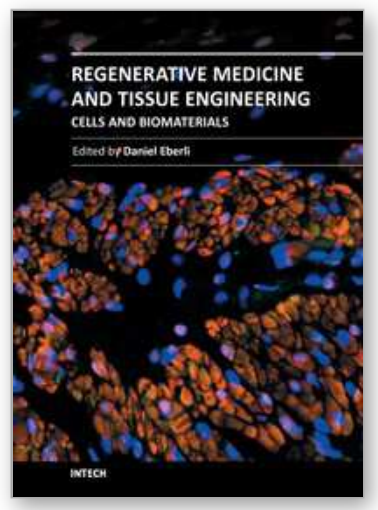

\author{
Regenerative Medicine and Tissue Engineering - Cells and \\ Biomaterials \\ Edited by Prof. Daniel Eberli
}

ISBN 978-953-307-663-8

Hard cover, 588 pages

Publisher InTech

Published online 29, August, 2011

Published in print edition August, 2011

Tissue Engineering may offer new treatment alternatives for organ replacement or repair deteriorated organs. Among the clinical applications of Tissue Engineering are the production of artificial skin for burn patients, tissue engineered trachea, cartilage for knee-replacement procedures, urinary bladder replacement, urethra substitutes and cellular therapies for the treatment of urinary incontinence. The Tissue Engineering approach has major advantages over traditional organ transplantation and circumvents the problem of organ shortage. Tissues reconstructed from readily available biopsy material induce only minimal or no immunogenicity when reimplanted in the patient. This book is aimed at anyone interested in the application of Tissue Engineering in different organ systems. It offers insights into a wide variety of strategies applying the principles of Tissue Engineering to tissue and organ regeneration.

\title{
How to reference
}

In order to correctly reference this scholarly work, feel free to copy and paste the following:

Ali Mobasheri, Stephen M. Richardson, Judith A. Hoyland, Constanze Buhrmann and Mehdi Shakibaei (2011). From Multipotent Cells to Fully Differentiated Connective Tissue Cells for Regenerative Medicine: Emerging Applications of Mesenchymal Stem Cells, Regenerative Medicine and Tissue Engineering - Cells and Biomaterials, Prof. Daniel Eberli (Ed.), ISBN: 978-953-307-663-8, InTech, Available from:

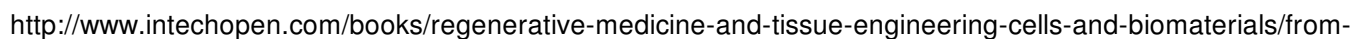
multipotent-cells-to-fully-differentiated-connective-tissue-cells-for-regenerative-medicine-eme

\section{INTECH}

open science | open minds

\section{InTech Europe}

University Campus STeP Ri

Slavka Krautzeka 83/A

51000 Rijeka, Croatia

Phone: +385 (51) 770447

Fax: +385 (51) 686166

www.intechopen.com

\section{InTech China}

Unit 405, Office Block, Hotel Equatorial Shanghai

No.65, Yan An Road (West), Shanghai, 200040, China

中国上海市延安西路65号上海国际贵都大饭店办公楼 405 单元

Phone: +86-21-62489820

Fax: $+86-21-62489821$ 